\author{
M.Zh. Burkeev ${ }^{1}$, G.K. Kudaibergen ${ }^{1}$, Ye.M. Tazhbayev ${ }^{1}$, \\ J. Hranicek ${ }^{2}$, G.K. Burkeyeva ${ }^{1}$, A.Zh. Sarsenbekova ${ }^{1}$ \\ ${ }^{I}$ Ye.A. Buketov Karaganda State University, Kazakhstan; \\ ${ }^{2}$ Charles University, Prague, Czech Republic \\ (E-mail: gulshahar90@mail.ru)
}

\title{
Synthesis and investigation of copolymer properties on the basis of poly(ethylene glycol)fumarate and methacrylic acid
}

\begin{abstract}
In the result of reaction of free radical copolymerization of poly(ethylene glycol)fumarate and methacrylic acid insoluble copolymers of different weight composition were obtained. Influence of ionic strength of the solution, organic solvents on the level of swelling of synthesized copolymers was studied. According to the result of the research, it is possible to make the conclusion that ratio of monomeric units in copolymer, as well as concentration of low-molecular components in the solution significantly influence the perceptivity of polymeric gels to the presence of low-molecular salts $\left(\mathrm{NaCl}\right.$ and $\left.\mathrm{CaCl}_{2}\right)$, organic solvents (DMSO, DMF, and ethanol). When the share of methacrylic acid is decreased in copolymer, the perceptivity of gels to admixtures of low-molecular salts and organic solvents is decreased. This is conditioned both by increase of the content of carboxyl groups in the macrochain, and density decrease of polymer network. Observed influence of ionic strength confirms contribution of both electrostatic and hydrophobic interactions in process of swellingcollapse of samples examined. It is shown that changing the nature of comonomer, we can obtain the hydrogels with the ability to turgesce or collapse at change of ionic strength, thermodynamic quality of the solution, and with variation of ratio of comonomer units it is possible to regulate the intervals of swelling and compression of polymer networks. As well, results of X-ray energy-dispersive microanalysis show that examined polymeric systems based on copolymers p-EGF - MAA might be in demand as sorbent agents in purification and beneficiation technologies.
\end{abstract}

Keywords: poly(ethylene glycol)fumarate, methacrylic acid, copolymer, hydrogel, polycondensation, swelling, collapse, unsaturated polyester, free radical copolymerization.

\section{Introduction}

New sphere studying the polymeric materials, whose properties might be changed depending on parameters of environment, appeared and started developing relatively recently. This new generation of materials is called «smart» or «intellectual» polymers. Distinctive features of «intellectual» polymers are in their additional functional abilities, which are out of the properties, defined by the structure of material [1]. Such materials play double or triple role - material itself with necessary characteristics, indicator for external influence, and, in some cases, device, «programmed» for definite behavior. Issue of synthesis, selection of initial reagents at obtaining of such polymer systems and their application, is especially urgent. Perspective reagents for development of intellectual systems are unsaturated polyesters, which are the products of polycondensation of polyatomic alcohols and carboxylic acids. Main feature of unsaturated polyesters is in ability to undergo easily the reaction of copolymerization (solidify) with vinyl monomers at room temperature without application of high pressures, without the release of volatile and other by-products [2-4]. Due to this, it becomes possible to apply the unsaturated polyesters as one of reagents at synthesis of «intellectual» polymers, which are widely applied in medicine, pharmacy, biotechnology, nanotechnology and lots of other branches of human life.

Basing upon the historical data, first time the concept of «copolymerization» of unsaturated polyesters was adopted by German scientist Benig [1]. Thus, multiple scientific works, patents, of both present and past periods, are devoted to the study of copolymerization of unsaturated polyesters with vinyl acetate, styrole and methylmetacrylate, simple and compound allyl ethers [2-4]. Analysis of literary sources showed the absence of information on free radical copolymerization of unsaturated polyesters with unsaturated carboxylic acids.

Earlier we obtained and examined the polymeric hydrogels based on polyglycol maleates with high sorbing properties. Results we obtained demonstrate the perspective of their application as moist sorbent agents in crop production [5] and as effective nanocatalysts [6]. However, with the aim of comprehensive enchanced studying of this unique valuable class, we considered interesting to continue the researches in this direction. 
In connection with the abovementioned, this work is devoted to the synthesis and study of physical and chemical properties of new polymeric hydrogels based on unsaturated polyester - poly(ethylene glycol) fumarate (p-EGF) solidified with methacrylic acid (MAA). We carried the analysis of sorbent properties of synthesized samples in water and salt solutions of low-molecular salts (LMS), organic solvents at change of their concentration and basic composition of polymeric network of copolymer.

\section{Experimental}

Initial p-EGF was obtained by reaction of polycondensation of fumaric acid and ethylene glycol at the temperature of 403-453 K [7, 8]. Reaction process was controlled by determination of an acid index and by volume of water released. Synthesized polyester is resinous low-melting substance of light-yellow color, soluble in chloroform and dioxane. The resin obtained was separated from the initial monomers by multiple rinsing with acetone.

Molecular mass of p-EGF was established by methods of light-scattering with nephelometer $2100 \mathrm{AN}$ of NACH brand and method of admeasurements of end groups, which amounts $2500 \mathrm{amu}$ [9]. Free radical copolymerization of p-EGF with MAA was carried in the solution of dioxane at different initial mass ratio of

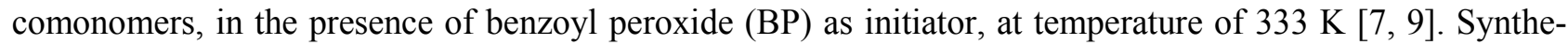
sized polymers, to separate them from the residuals of unreacted monomers, were multiple rinsed with dioxane and dried with vacuum till the constant mass. Compositions of copolymers obtained were determined with potentiometric titration and according to the residual quantity of monomers by method of chromato-mass spectroscopy with Agilent 7890A mass-selective detector Agilent 5975C [7, 9-11].

Equilibrial level of swelling of hydrogels was determined by gravimetric method. Level of swelling of samples $(\alpha)$ was calculated as the ratio of mass of turgid hydrogel in point of equilibrial swelling to its initial mass in dry condition $[1,5,6]$. IR-spectra of samples were registered in pills with $\mathrm{KBr}$ with spectrometer FSM 1201. Electronic microscopic study was held with raster electron microscope (REM) MIRA 3 of TESCAN brand. Studies were carried at accelerating potential $20 \mathrm{kV}$ [11].

\section{Results and discussions}

High-turgid polymeric hydrogels are the system that easily react the changes of external environment. Conduct of such hydrogels in solutions of low-molecular salts is studied in details, in particular, the ability of hydrogels to make the redistribution of their concentrations $[1,5,6,12]$. Researches of copolymers of poly(ethylene glycol) fumarate show that the latter are sensible to the change of environment. This suggests the perceptibility of studied systems to ions of low-molecular salts and organic solvents.

At reaction of p-EGF with MAA in presence of initiator of polymerization reaction, their joint polymerization happens, which leads to the formation of non-fusible polymer of three-dimensionally cross-linked structure $[1,7]$. Reaction of free radical copolymerization of p-EGF with MAA proceeds under the following scheme presented in Figure 1.

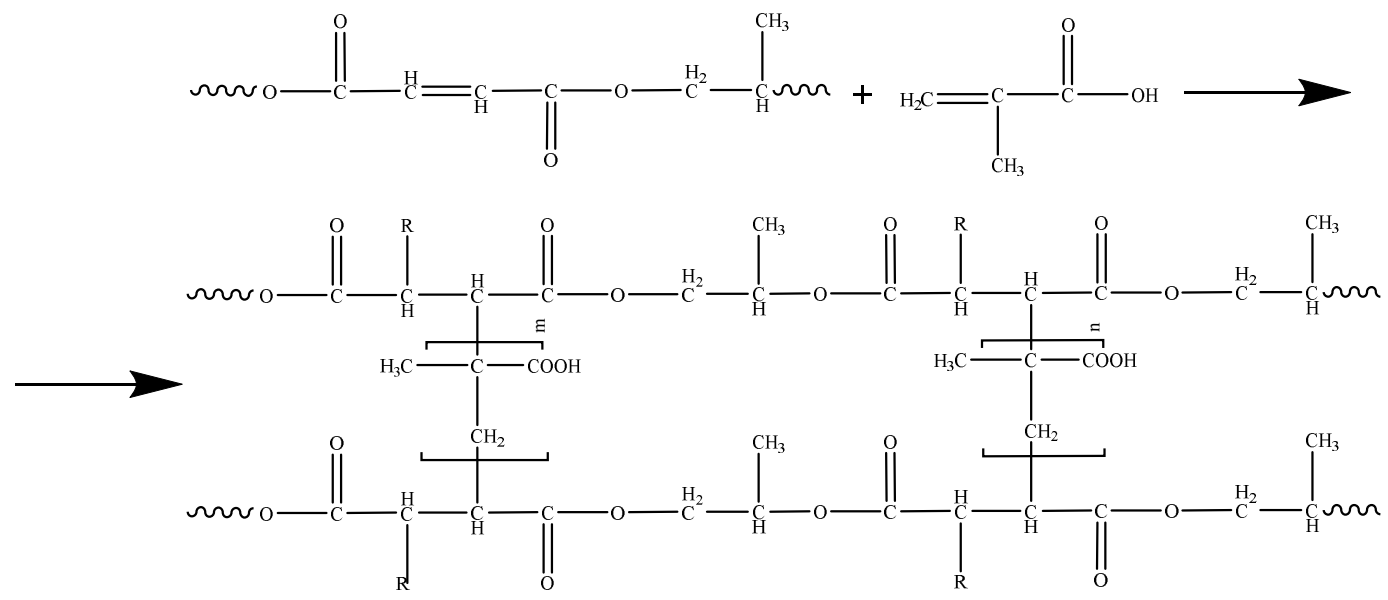

Figure 1. Reaction scheme of free radical copolymerization p-EGF with MAA

Results for copolymerization of p-EGF with MAA are shown in Table. Yield of copolymer amounts 73 to $87 \%$. 
As we see in Table, at any ratio of initial mixture, copolymer is beneficiated with links of MAA, at that yield and level of swelling is decreased progressively as reduction of the latter.

T a ble

Dependence of composition of copolymers on composition of initial mixture at free radical copolymerization of p-EGF $\left(M_{1}\right)$ with MAA $\left(M_{2}\right)[B P]=8 \mathrm{~mole} / \mathrm{m}^{3}, T=333 \mathrm{~K}$

\begin{tabular}{|c|c|c|c|c|}
\hline \multicolumn{2}{|c|}{ Composition of initial mixture, mass \% } & \multicolumn{2}{|c|}{ Composition of copolymer, mass \% } & \multirow{2}{*}{ Yield, \% } \\
\hline $\mathrm{M}_{1}$ & $\mathrm{M}_{2}$ & $m_{1}$ & $m_{2}$ & 87.30 \\
\hline 10.03 & 89.97 & 6.65 & 93.35 & 80.73 \\
\hline 15.08 & 84.92 & 10.23 & 89.77 & 75.07 \\
\hline 25.07 & 74.93 & 19.25 & 80.75 & 72.52 \\
\hline 50.05 & 49.95 & 42.09 & 57.91 & \\
\hline
\end{tabular}

Copolymers were identified according to data of IR-spectra in accordance with the Figure 2. Lines, describing the range $1550 \sim 1620 \mathrm{~cm}^{-1}$ are related to the link $\mathrm{C}=\mathrm{O}$. At the same time, absorption bands in IR-spectrum copolymers p-EGF-MAA in $1758 \sim 1763 \mathrm{~cm}^{-1}$ and $2994 \sim 2997 \mathrm{~cm}^{-1}$ characterize the links $\mathrm{C}=\mathrm{O}$ and $-\mathrm{CH}_{2}$ respectively, and peaks at $1184 \sim 1190 \mathrm{~cm}^{-1}$ are peculiar for COC - link. Besides, absorption bands at $1452 \sim 1457 \mathrm{~cm}^{-1}$ and $1382 \sim 1389 \mathrm{~cm}^{-1}$ conform to link $-\mathrm{CH}\left(\mathrm{CH}_{2}\right)$.

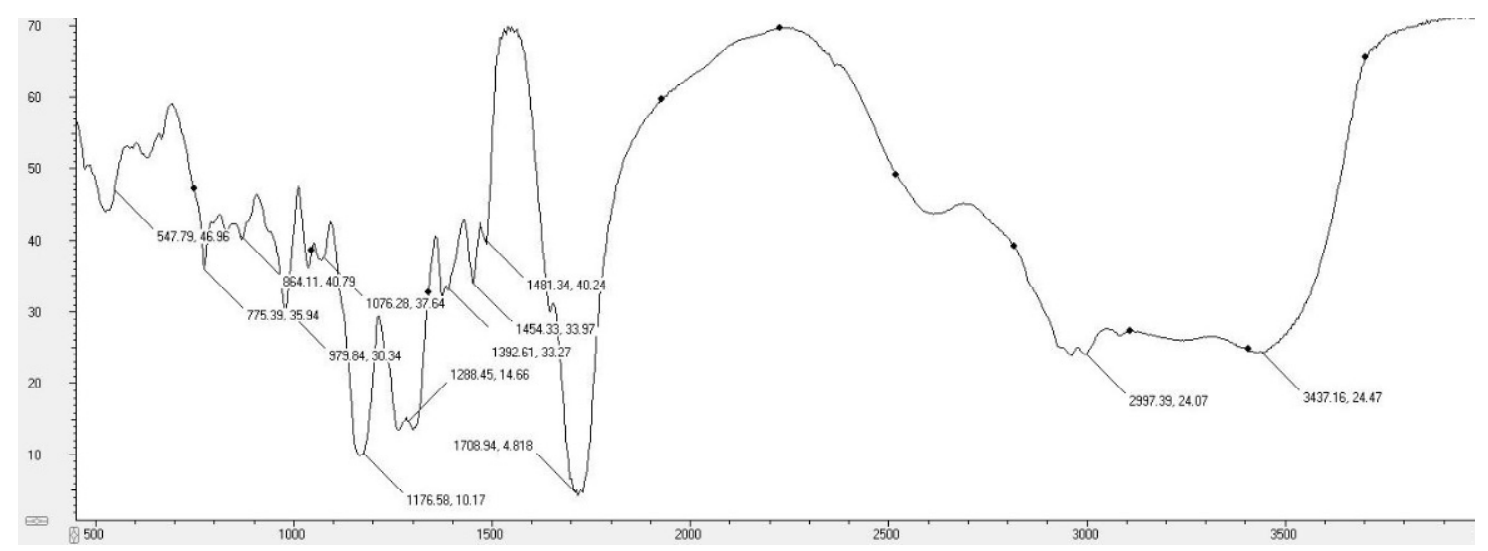

Figure 2. IR-spectrum of p-EGF-MAA

Literature [12] shows that presence of low-molecular component in the solution may cause both swelling, and collapse of polymeric network. According to [12], addition of low-molecular salt influences significantly the polyelectrolytic gels causing the shielding of effects related to the state of charge of the network. Basing upon abovementioned, we can suggest that nature of reaction of linked polymer with ions of mono- and polyvalent salts depends on its chemical composition. Figures 3, 4 show the experimental data of dependence of level of swelling of synthesized samples on concentration of $\mathrm{NaCl}$ and $\mathrm{CaCl}_{2}$, respectively.

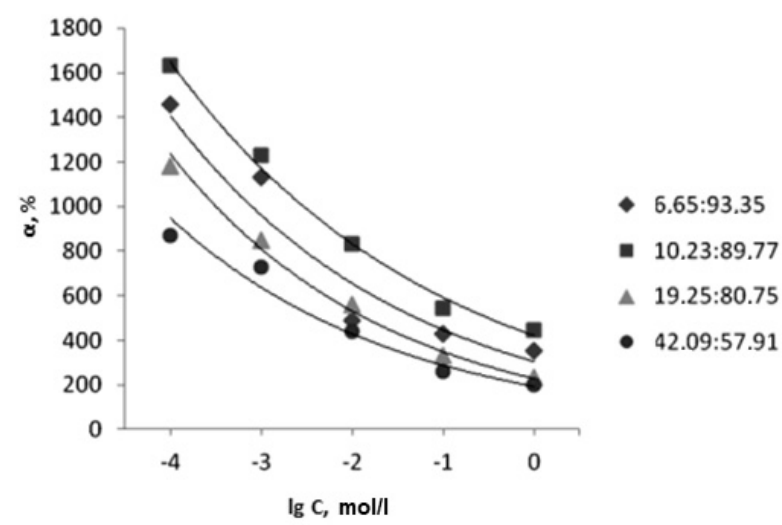

Figure 3. Influence of $\mathrm{NaCl}$ salt concentration on level of swelling of copolymers p-EGF-MAA 


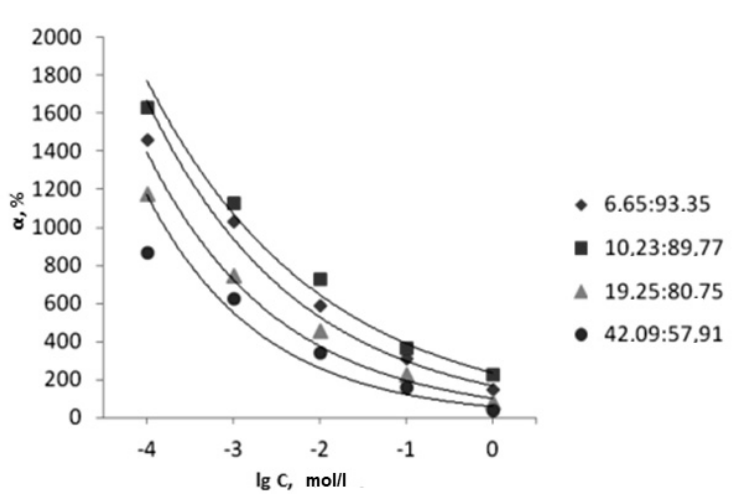

Figure 4. Influence of $\mathrm{CaCl}_{2}$ salt concentration on level of swelling of copolymers p-EGF-MAA

Thus, at adding of low-molecular salt $\mathrm{NaCl}$ to the external solution, dimensions of samples of polymeric network are reduced to some minimal value (Fig. 3). According to analysis of hydrogel properties, case of chemical contraction may be implemented at suppression of LMS of electric attraction of like-charged groups. From this viewpoint, such conduct of samples tested in LMS solution is explained by the fact that dependence of level of swelling on salt concentration is subject to polyelectrolytic mode $[1,5,6,12]$.

With concentration increase of low-molecular compositions, we observe the collapse of copolymers tested. It should be emphasized that according to the results obtained, ratio of monomeric units in copolymers to the presence of low-molecular salts influences the conduct of hydrogels. Thus, with increase of share of MAA in copolymers, sensibility of gels to salts admixtures is increased, and transition is observed at higher values of salts.

As continuation of research, we examined the influence of bivalent salt $\mathrm{CaCl}_{2}$ on conduct of hydrogels of p-EGF-MAA. Figure 4 shows the experimental data for swelling in presence of bivalent salt. Comparing these results with the experimental studies of influence of monovalent salt, we can note the fact that curves of dependence of swelling of copolymers tested in the presence of $\mathrm{CaCl}_{2}$ and $\mathrm{NaCl}$ are of similar nature. It should be noted that decrease of sorption capacity of hydrogels is observed at lesser concentrations of bivalent salt. This might be related to the number of reasons: first, bivalent ions are stronger attracted by oppositely charged groups of the network, compared to monovalent ones; second, bivalent ions may neutralize the charge of large number of opposed-charged ions inside the network [5, 6]. Experimental data we obtained are coherent with literature data [12].

Considering the abovementioned, basing upon the widely known theoretical principles and processes, peculiar for polyelectrolytic gels, it seemed interesting to study the microstructure of sample of p-EGF-MAA 10.23:89.77 mas.\%. With that in mind, electronic and microscopic studies of turgid samples in water and salt solutions of $\mathrm{NaCl}$ and $\mathrm{CaCl}_{2}$ were carried out. Results of the research are shown in Figure 5.
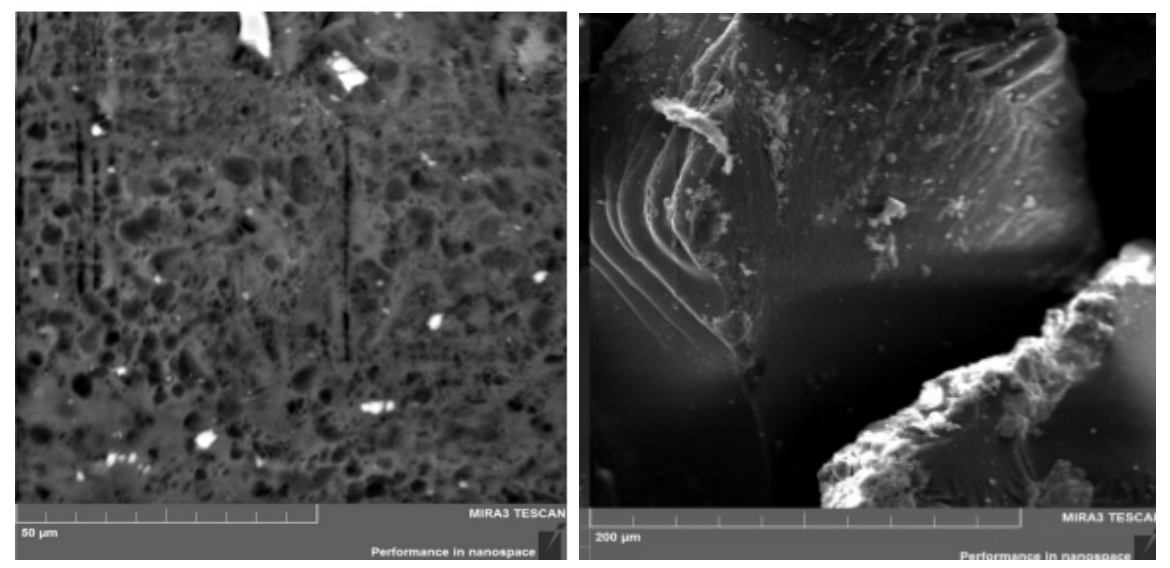

10.23:89.77 mas.\% $\mathrm{NaCl}$ (at the left) and $\mathrm{CaCl}_{2}$ (at the right)

Figure 5. Electronic and microscopic figures of p-EGF-MAA 
To confirm the presence of ions of $\mathrm{Ca}^{2+}$ we carried out the X-ray energy-dispersive microanalysis $\mathrm{X}$ Act (Oxford Instruments) of copolymer p-EGF-MAA 10.23:89.77 mas.\%. This microanalysis allows detecting locally the elemental composition on the surface of the sample (Fig. 6). Analysis was carried out by the method of mapping of sample surface. At detection, it was considered that the test was carried with carbon adhesive tape, and carbon content was not considered. At imposition of allocation maps of chemical elements, the presence of elements composing this microstructure was obtained.

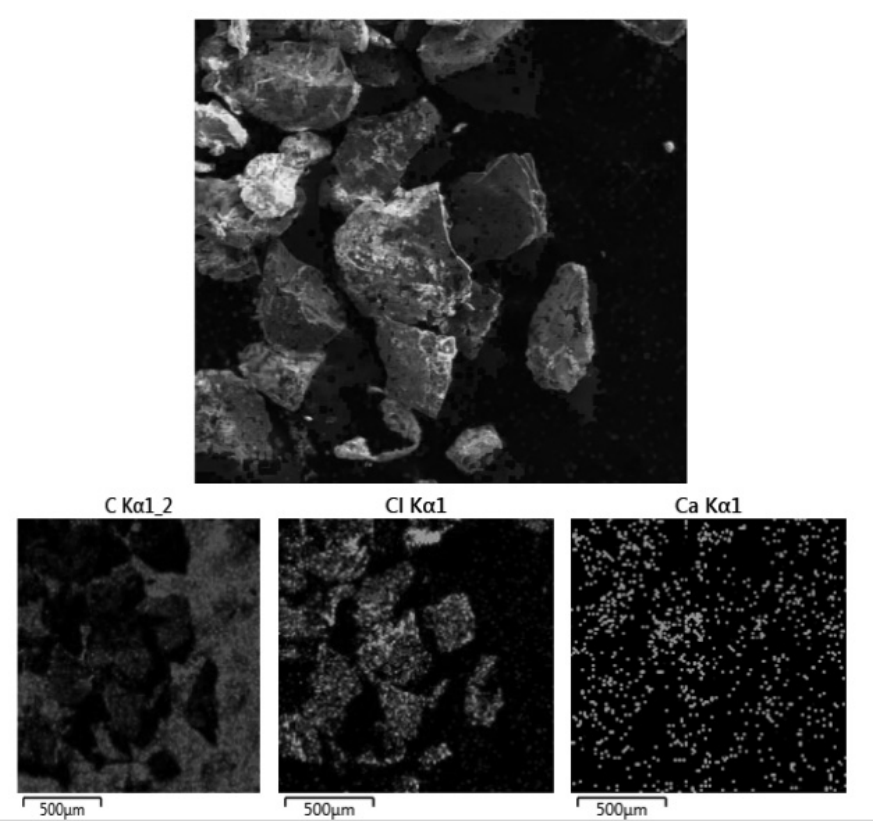

Figure 6. Figure of secondary electrons of copolymer p-EGF-MAA 10.23:89.77 mas.\% with ions of $\mathrm{CaCl}_{2}$ salt and mapping in this part

Results of X-ray energy-dispersive microanalysis of the sample fully confirm the composition of the product, and distribution of chemical elements in microstructure confirm the presence of such elements as carbon, chlorine and calcium.

In continuation of researches, to obtain the more aggregate figure of influence of different factors of environment on sorbing ability of samples tested, the influence of organic solvents on level of swelling of p-EGF-MAA with composition of 10.23:89.77 mas.\% was studied. As organic component, dimethylformamide (DMF), dimethylsulfoxide (DMSO) and ethanol were selected; their content if the mixture with water varied from 0.1 till 1.0 volume ratios $\left(\mathrm{n}_{0}\right)$. Selection of these solvents was based upon the difference in their polarity.

At addition to environment, being the polymer turgid in water, among organic solvents gradual reduction of samples dimensions is observed, which is the result of deterioration of thermodynamic quality related to the presence of solvents $[1,5,12]$. It shall be noted that function $\alpha\left(\mathrm{n}_{0}\right)$ is not changed in jerks, thus, this process cannot be examined as phase change. As well, it shall be noted that the nature of organic solvents influences the type of influential curves. Thus, hydrogels become most globular in ethanole, compared to the systems DMF-water, DMSO-water. These phenomena might be explained by the volume of polarity and permittivity of examined organic components [12].

\section{Conclusions}

Thus, the conclusion might be made that possibilities of control of physical and chemical properties of polymers based on poly(ethyleneglycol) fumarate, demonstrated in the thesis, allow to develop new polymeric materials of polyfunctional destination with preset conduct program. Besides, considering the results of $\mathrm{X}$-ray energy-dispersive microanalysis, we can make a conclusion that tested systems based on copolymer p-EGF might be in demand as sorbents in purification and beneficiation technologies.

The work is done within the frameworks of grant financing of scientific researches for 2018-2020 by Ministry of education and science of the Republic of Kazakhstan subject to the project topic 
No. AP05131541 «Development of theoretical and practical bases for the synthesis of new «intelligent» polymers based on polyethylene-(propylene) glycol fumarate».

\title{
References
}

1 Burkeev M. Zh. New Polyampholyte polymers based on polypropylene glycol fumarate with acrylic acid and dimethylaminoethyl methacrylate / M.Zh. Burkeev, G.K. Kudaibergen, G.K. Burkeeva et al. // Russ. J. Appl. Chem. — 2018. Vol. 91, No. 7. - P. 1145-1152.

2 Бениг Г.В. Ненасыщенные полиэфиры: строение и свойства / Г.В. Бениг. - М.: Химия, 1968. - 253 с.

3 Пот У. Полиэфиры и алкидные смолы: монография / У. Пот. - М.: КТС, 2009. — 380 с.

4 Коляго Г.Г. Материалы на основе ненасыщенных полиэфиров / Г.Г. Коляго, В.А. Струк. — Минск: Наука и техника, 1990. - $143 \mathrm{c}$.

5 Burkeev M.Zh. Effect of external factors on the swelling of hydrogels based on poly(ethylene glycol)maleate with some vinyl monomers / M.Zh. Burkeev, E.M. Tazhbaev, G.K. Burkeeva et al. // Russ. J. Appl. Chem. — 2013. — Vol. 86, No. 1. — P. 6368.

6 Burkeev M.Zh. Nanocatalytic systems based on poly(ethylene glycol maleate) - acrylamide copolymers / M.Zh. Burkeev, E.M. Tazhbaev, G.K. Burkeeva, A.K. Kovaleva // Russ. J. Appl. Chem. - 2015. — Vol. 88, No. 2. — P. 314-319.

7 Kudaibergen G.K. Constants and parameters of radical copolymerization of poly(ethylene glycol fumarate) with acrylic acid / G.K. Kudaibergen, G.K. Burkeeva et al. // Chemical journal of Kazakhstan. — Vol. 61, No. 1. — 2018. — P. $215-222$.

8 Патент № 31052. Казахстан. Способ получения ненасыщенных полиэфирных смол на основе пропиленгликоля, фталевого ангидрида и фумаровой кислоты / Буркеев М.Ж., Тажбаев Е.М. и др. Опубл. 16.03.2016.

9 Burkeev M.Zh. The number average and mass average molecular masses of polyethylene(propylene)glycol fumarates / M.Zh. Burkeev, G. Kudaibergen, G.K. Burkeeva et al. // Bulletin of the Karaganda University. Chemistry series. - 2018. — Vol. 90, No. 2. - P. 17-22.

10 Гольберт К.А. Введение в газовую хроматографию / К.А. Гольберт, М.С. Вигдергауз. - 3-е изд., перераб. и доп. М.: Химия, 1990. - 352 с.

11 Золотов Ю.А. Физико-химические методы анализа / Ю.А. Золотов, Е.Н. Дорохова, В.И. Фадеева. — М.: Высш. шк., 2000. - $356 \mathrm{c}$.

12 Филиппова О.Е. «Восприимчивые» полимерные гели / О.Е. Филиппова // Высокомолекулярные соединения. — 2000. — T. 42, № 12 . - C. 2328-2352.

\author{
М.Ж. Бүркеев, Г.Қ. Құдайберген, Е.М. Тажбаев, \\ Я. Граничек, Г.К. Бүркеева, А.Ж. Сарсенбекова
}

\section{Полиэтиленгликольфумараттың метакрил қышқылы негізіндегі сополимерлердің синтезі мен зерттелуі}

\begin{abstract}
Полиэтиленгликольфумарат пен метакрил қышқылының радикалды сополимерлену реакциясымен әртүрлі массалы қатынастағы ерімейтін сополимерлер алынды. Синтезделген сополимерлердің ісіну дәрежесіне ерітіндінің иондық күші, органикалық еріткіштердің әсері зерттелді. Зерттеу нәтижесі бойынша полимерлі гельдердің сезімталдығына төмен молекулалы тұздардың $\left(\mathrm{NaCl}\right.$ пен $\left.\mathrm{CaCl}_{2}\right)$, органикалық еріткіштер (ДМСО, ДМФА, этанол), сополимердегі буындардың қатынасы, сонымен қатар ерітіндегі төмен компоненттердің концентрациясы айтарлықтай әсер етеді. Сополимердегі метакрил қышқылының мөлшерінің азаюы гельдің төменмолекулалы тұздар мен органикалық еріткіштерге сезімталдығы төмендейді. Бұл макротізбектегі карбоксил топтардың көбеюі мен полимердің тордың тығыздығының азаюымен негізделген. Ионды күшінің бақыланатын әсері зерттеліп жатқан сынамалардың ісінуі-коллапс үрдісі кезінде гидрофобтық және электростатикалық өзара әрекеттесулердің үлесін растайды. Сомономердің табиғатын өзгерте отырып, иондық күш, ерітіндінің термодинамикалық қасиеттерін, ісінуге немесе коллапстауға қабілетті гидрогельдерді алуға болатындығы, сонымен қатар сономердің буындарының қатынасын өзгерте отырып, полимерлі торлардың ісіну мен сығылу интервалдарын реттеуге болатындығы көрсетілді. Ренгтгенді энергодисперсионды микросараптама нәтижелері негізінде п-ЭГФ - МАҚ негізіндегі сополимерлерді полимерлі жүйелер сорбенттер ретінде тазартқыш және байыту технологияларында қолданыла алады.
\end{abstract}

Кілm сөздер: полиэтиленгликольфумарат, метакрил қышқылы, сополимер, гидрогель, поликонденсация, ісіну, коллапс, қанықпаған полиэфирлі шайыр, радикалды сополимерлену. 


\title{
М.Ж. Буркеев, Г.К. Кудайберген, Е.М. Тажбаев, \\ Я. Граничек, Г.К. Буркеева, А.Ж. Сарсенбекова \\ Синтез и исследование свойств сополимеров на основе полиэтиленгликольфумарата и метакриловой кислоты
}

\begin{abstract}
Реакцией радикальной сополимеризации полиэтиленгликольфумарата и метакриловой кислоты получены нерастворимые сополимеры различного массового состава. Исследовано влияние ионной силы раствора, органических растворителей на степень набухания синтезированных сополимеров. По результатам исследований можно сделать вывод, что на восприимчивость полимерных гелей к присутствию низкомолекулярных солей $\left(\mathrm{NaCl}\right.$ и $\left.\mathrm{CaCl}_{2}\right)$, органических растворителей (ДМСО, ДМФА, этанол) существенно влияют соотношения мономерных звеньев в сополимере, а также концентрация низкомолекулярных компонентов в растворе. С уменьшением в сополимере доли метакриловой кислоты понижается чувствительность гелей к добавкам низкомолекулярных солей, органических растворителей. Это обусловлено как повышением содержания карбоксильных групп в макроцепи, так и снижением плотности полимерной сетки. Наблюдаемое влияние ионной силы подтверждает вклад как электростатических, так и гидрофобных взаимодействий в процессе набухания-коллапса исследуемых образцов. Показано, что, изменяя природу сомономера, можно получать гидрогели, способные набухать или коллапсировать при изменении ионной силы, термодинамического качества раствора, а варьируя соотношение звеньев сомономеров, можно регулировать интервалы набухания и сжатия полимерных сеток. Также из результатов рентгеновского энергодисперсионного микроанализа следует, что исследуемые полимерные системы на основе сополимеров п-ЭГФ - МАК могут быть востребованы в качестве сорбентов в очистительных и обогатительных технологиях.
\end{abstract}

Ключевые слова: полиэтиленгликольфумарат, метакриловая кислота, сополимер, гидрогель, поликонденсация, набухание, коллапс, ненасыщенная полиэфирная смола, радикальная сополимеризация.

\section{References}

1 Burkeev, M.Zh., Kudaibergen, G.K., \& Burkeeva, G.K. et al. (2018). New Polyampholyte polymers based on polypropylene glycol fumarate with acrylic acid and dimethylaminoethyl methacrylate. Russ. J. Appl. Chem., 91(7), 1145-1152.

2 Benig, G.V. (1968). Nenasyshchennye poliefiry: stroienie i svoistva [Unsaturated polyesters: structure and properties]. Moscow: Khimiia [in Russian].

3 Pot, U. (2009). Poliefiry i alkidnye smoly [Polyesters and alkyd resins]. Moscow: KTC [in Russian].

4 Kolyago, G.G., \& Struk, V.A. (1990). Materialy na osnove nenasyshchennykh poliefirov [Materials based on unsaturated polyesters]. Minsk: Nauka i tekhnika [in Russian].

5 Burkeev, M.Zh., Tazhbaev, E.M., \& Burkeeva, G.K. et al. (2013). Effect of external Factors on the swelling of hydrogels based on poly(ethylene glycol)maleate with some vinyl monomers. Russ. J. Appl. Chem., 86(1), 63-68.

6 Burkeev, M.Zh., Tazhbaev, E.M., Kovaleva, A.K., \& Burkeeva, G.K. et al. (2015). Nanocatalytic systems based on poly(ethylene glycol maleate)acrylamide copolymers. Russ. J. Appl. Chem., 88(2), 314-319.

7 Kudaibergen, G.K., \& Burkeeva, G.K. et al. (2018). Constants and parameters of radical copolymerization of poly(ethylene glycol fumarate) with acrylic acid. Chemical journal of Kazakhstan, 61(1), 215-222.

8 Burkeyev M.Zh., \& Tazhbayev Ye.M. et. al. (2016). Sposob polucheniia nenasyshchennykh poliefirnykh smol na osnove propilenhlikolia, ftalevoho anhidrida i fumarovoi kisloty [Method for the preparation of unsaturated polyester resins based on propylene glycol, phthalic anhydride and fumaric acid]. Patent № 31052. Kazakhstan. Published 16.03.2016 [in Russian].

9 Burkeev, M.Zh., Kudaibergen, G., \& Burkeeva, G.K. et al. (2018). The number average and mass average molecular masses of polyethylene(propylene)glycol fumarates. Bulletin of the Karaganda University. Chemistry series, 90(2), 17-22.

10 Golbert, K.A., \& Vigdergauz, M.S. (1990). Vvedenie v hazovuiu khromatohrafiiu [Introduction to Gas Chromatography]. Moscow: Khimiia [in Russian].

11 Zolotov, Yu.A., Dorokhova, E.N., \& Fadeeva, V.I. (2000). Fiziko-khimicheskie metody analiza [Physico-chemical methods of analysis]. Moscow: Vysshaia shkola [in Russian].

12 Filippova, O.E. (2000). «Vospriimchivye» polimernye heli [Susceptible Polymer Gels]. Vysokomolekulyarnye soedineniia Polymer Science, 42(12), 2328-2352 [in Russian]. 